\title{
TEOSOFI TARIQA AND THE PRINCIPLES, RITUALS, AND RATIONALITY AS A RELIGIOUS MOVEMENT
}

\author{
M. Dimyati Huda \\ State Institute of Islamic Studies Kediri, Indonesia \\ E-mail: dimyatihuda64@gmail.com \\ Nur Chamid \\ State Institute of Islamic Studies Kediri, Indonesia \\ E-mail: nurchamid2019@gmail.com
}

\begin{abstract}
This article seeks to reveal the principles, rituals, and rationality of a religious movement named 'Teosofi Tariqa,' a Sufi order that has existed since 1908 in Indonesia. The importance of this research is based on the different perspectives from other religious movements offered by Teosofi Tariqa, and also in terms of religious conflict resolution in this country. This research used a qualitative approach, which relied significantly on several instruments, such as observations, interviews, and documentation for data collection, while the Miles and Huberman versions were used for the analysis. It was discovered that the Teosofi Tariqa in Surabaya promulgates tolerance and diversity principles towards other people regardless of their religions. As a Sufi order, the movement emphasizes mysticism and meditation as a means of submission, obedience, and servitude to the absolute and rational God. It also emphasizes the importance of community services.
\end{abstract}

Keywords: Teosofi Tariqa, Religious Movements, Theology, Meditation.

\section{Introduction}

Since the beginning, most Muslim communities in Indonesia are adhering to the concept of Ahl al-Sunnah wa al-Jamā'ah, although some historians said that it was the Shia who played an important role in developing Islam on earth. However, there is no strong evidence. A large number of preachers, scholars, and Muslim figures in Java, Kalimantan, and Mataram regions are Sufi figures who were affiliated with Sunni schools such as Shäfíiyya and Ash'ariyya. Thus, the 
average of Indonesian Muslims adheres to Nahdlatul Ulama, Muhammadiyah, and Persatuan Islam. ${ }^{1}$ All of these ideologies or schools are allowed to develop under the legal protection of Pancasila freely. Thus, it reveals the majority and minority understandings.

Some data showed that minorities continue to grow in the midst of Sunnis' domination as understood by the majority groups. Ramli's research (2017) stated that there is an understanding of minorities as a splinter of ideology in Indonesia has developed quickly. Even for minority deviant sects, there are more than 250 ideologies, 20\% (around 50 or more) are scattered in the Java region. ${ }^{2}$ This number represents minority sects in the form of theological, theosophical, tariqa, and socio-political. Indirectly, conflict friction as a logical consequence of the reality of ideological differences, be it social, theological, political, or academic in a certain scope, cannot be avoided.

So far, the developing understanding of minorities does not always bring fresh air to our religious harmony. Indonesia's investment released that the radical Islamic movement departed from the understanding of minorities, which saw their ways of religion as

\footnotetext{
${ }^{1}$ Along with the times, since the stepping down of the new Tarekat up to now, the two socio-religious organizations that dominate in Indonesia are Nahdlatul Ulama and Muhammadiyah. These two organizations can survive very properly and are stable. Many observers said that the existence of the two-run according to different duties, as revealed by historians that both have in common and are related to history. NU has the characteristics of the people who are from villages and lowerclass communities, while Muhammadiyah is part of an urban or city people in a community. For more details, see Faisal Ismail, "The Nahdlatul Ulama: Its Early History and Contribution to the Establishment of Indonesian State", Journal of Indonesian Islam, Vol. 5, No. 2 (2011). More details are also presented by Khoirun Niam, "Nahdhatul Ulama and the Production of Muslim Intellectuals in the Beginning of $21^{\text {st }}$ Century Indonesia", Journal of Indonesian Islam, Vol. 11, No. 2 (2017), 147.

2 Java has indeed become a fertile land for the development of schools and tariqa, besides, it is a part of Javanese cultures that has been existing for a long time, Javanese society is known for its religious base in Indonesia, this is due to the culture and history that can be preserved by the Javanese people. Islamic Clerics such as Sunan (Islamic leaders or such so) and their followers. Even Islam first appeared in the archipelago. Some said that it was started in Java. To tackle radical sects, the government of Susilo Bambang Yudhoyono (former president) had entrusted the MUI fatwas to be supported and guarded regarding the radical acts. See more clearly in Ramli Abdul Wahid, "Aliran Minoritas dalam Islam di Indonesia", Journal of Contemporary Islam and Muslim Societies, Vol. 1, No. 2 (2017), 142.
} 
the truest (truth claim). ${ }^{3}$ The various minority understandings portrayed as radicalism all have central theological characteristics, namely a minority religious sect or ideology that operates in the fields of uluhiyya or theocratic, excluding social, political, or other elements.

Zaki Mubarak's study showed that the dissection of religious understanding is based on many factors, including, first, dissatisfaction with government policies related to economy, politics, and religion. This is supported by a database of the Global Terrorism Database (2007), which concluded that from 1970-2007, it was noted that out of 421 acts of radicalism in religious beliefs were suspected by policy elements of authorities. ${ }^{4}$ The second, religious fanaticism. A view on the justification of extreme religious theology, sometimes releasing socio-political elements, but it was spoken in the name of religion. As a remnant or derivative of the ideology Darul Islam since 1950 and the jihad commando (Komji) in the late 1970s claimed to be the truest Islamic ideology. ${ }^{5}$ The third, centralistic ideology. Namely, an understanding that operates only in the realm of religious rituals, without social, political, or scientific interpretation. However, this way of thinking without being silent-according to some observers-has become the embryo of the emergence of radicalism.

Therefore, Mohammed Hafez in his research said that the history of the classical world up to now, as well as in Indonesia to

3 "Minoritas Paling Berbahaya: Islam Radikal di Indonesia", in https://www.matamatapolitik.com accessed on Agustus 11, 2019.

4 The database report is explained more recently that up to 2014 , there have been 729 sects of radical minority sects that have been successfully resolved by the government through MUI's cooperation with other religious institutions. This minority religious sect derives from the transfer of extreme theological meaning that has occurred from generation to generation. M. Zaki Mubarak, "Dari NII ke ISIS: Transformasi Ideologi dan Gerakan dalam Islam Radikal di Indonesia Kontemporer", Jurnal Episteme, Vol. 10, No. 1 (2015), 79.

5 Almost all radical movements adopt the character of fanaticism in religious understanding; this fanaticism, in turn, is not supported and seems to be considered an enemy by the authorities. Therefore, anyone who is different and opposes is considered an infidel. See M. Zaki Mubarak, Geneologi Islam Radikal di Indonesia: Gerakan, Pemikiran, dan Prospek. Demokasi (Jakarta: LP3ES, 2008), 78. See also the research results of Limas Dodi, that; as an ideology, religion functions to legitimize an action. It functions as a norm or rule that determines whether an action is good or bad, whether an action is right or wrong. Because religion speaks the truth, it is not uncommon for acts of violence to be committed in the name of God. Limas Dodi, "Ideologi Agama dalam Praktik Dominasi antara LDII Versus Non-LDII di Jombang", Teosofi: Jurnal Tasawuf dan Pemikiran Islam, Vol. 8, No. 1 (2018), 192. 
remote areas, has the potential to rise religious movements, both ideological and violent, due to several reasons; first, the role of the state which is felt to protect all groups among the reality of the majority. The assumption of Khiläfah and Imamah is the cause of this factor. Second, repressive actions are ridden with the perception of "not being appreciated" or "not being considered". Third, the meaning of jihad is wrong. Different religious views lead to the assumption that it is permissible to carry out jihad. ${ }^{6}$

From these various factors, there is an entry problem as the main factor in disseminating religious ideas which react radically and is prone to conflict, namely normative centralism in the religious realm, which creates a complex problem, including fanaticism, the system of kbiläfah, jïhäd fi sabil Allah and other elements that cause radicalism to emerge. What is meant by normative centralism is to understand religion in the text alone, without further elaborating on the sources, historicity, philosophy, and so forth. Here is where the problem of religious understanding is often unable to be properly parsed.

Therefore, this study raised the locus of religious understanding that is capable of elaborating on the meaning of religious ideology, such as the Teosofi Tariqa where the base is in Surabaya, with the ritual activities of the Sanggar Penanggarungan, which regularly conducts theosophy studies as a tariqa that has existed since the 1980s. The concept of a religious trilogy is abbreviated as SMP (Study, Meditation, and Service). This tariqa holds on the priority of the principles of science, philosophy, and social science. These three ritual concepts are a cure for the disease of fanaticism, imamah, and kbiläfah, which is partially understood. In turn, this research becomes a description of the religious understanding of the archipelago.

The author has searched various research journals, but no one has conducted the same and unique field of the study. For instance, Sawaludin Siregar (2018) examined religious understanding in the Naqshabandiyya Tariqa, focusing on haqq al-yaqin; his research was about ritualistic theological elements that are vulnerable to

\footnotetext{
6 The research was carried out to the archipelago periphery areas using a social movement approach, apart from these three factors. For the marginalized community, radicalism often arises because of the authorities who instill religious extremism. See Mohammed Hafez, "Dari Peminggiran ke Pembantaian" in Quintan Wictorowicz, Aktivisme Islam: Pendekatan Teori Gerakan Sosial Jakarta: Balitbang Kemenag, 2007), 190.
} 
internalization. $^{7}$ Despite the social side of showing society's understanding, in science, it is said that this thing is not an urgency. Furthermore, Armin Tedy (2017) examined the Siddīqiyya Tariqa, as well as Naqshabandiyya is a deeper study of elements of theological ritual. ${ }^{8}$ Therefore, the research seems repetitive and normative.

This research examined the trilogy; study, meditation, and devotion. A concept of religious understanding elaborates on all theological, social, and humanistic aspects. This difference in the process creates significance and recommendations for the sustainability of religious understanding, both the majority and the minority that develop in Indonesia. This research is useful for all groups because it contains both academic and spiritual sides.

Therefore, to maintain the study's validity, this study took data directly into the field, using a purposive sampling technique. ${ }^{9}$ The data collection method consisted of interviews, observation, and documentation. Because it is qualitative, the researcher acts as a participatory (observer participatory). ${ }^{10}$ After the data was collected, the data were not directly used as the study's final data. However, it was analyzed thoroughly using analytical descriptive analysis techniques to know the results of data descriptions and then reanalyzed using other data obtained. If there are inequalities, then the data were collected in which the most logical data was got academically. ${ }^{11}$

7 Sawaluddin Siregar, "The Pattern of Religious Understanding of the West Pasaman Simpang Empat Community (Study of the Haqqul Yaqin Sect of the Naqsabandiyah Tarekat)", Fitrab: Jurnal Kajian Ilmu-ilmu Keislaman, Vol. 4, No. 1 (2018), 43-66.

8 Armin Tedy, "The Mutabaroh Tarekat in Indonesia (Study of the Shiddiqiyyah Tarekat and Its Teachings)", Jurnal El-Afkar, Vol. 6, No. 1 (2017), 31-42. Similar research (read; Siddīqiyya objects) has also been conducted by Limas Dodi, "Antara Spiritualitas dan Realitas Tarekat Shiddiqiyyah dalam Bingkai Fenomenologi Annemarie Schimmel", Prosiding Nasional Pascasarjana LAIN Kediri, Vol. 1, No. 1 (2018), 29-54.

${ }_{9}$ Burhan Bungin, Penelitian Kualitatif: Komunikasi, Ekonomi, Kebijakan Publik, dan Ilmu Sosial Lainnya (Jakarta: Kencana Prenada Media Group, t.th.), 108.

10 Julia Brenen, Memadu Metode Penelitian: Kualitatif dan Kuantitatif (Yogyakarta: Pustaka Pelajar, 2005), 11.

11 Sugiyono, Metode Penelitian Kuantitatif Kualitatif dan R \& D (Bandung: Alfabeta, 2014), 246. 


\section{History of the Teosofi Tariqa}

Starting from its history, the Teosofi Tariqa's existence in Surabaya is once related to the roots of Teosofi in the West. According to De Tollenaere (1874), the Theosophy school has an international scale network as an esoteric school to maintain eternal wisdom as the essence of truth in religion (religious) or scientific. This is so that universal humanity can be maintained. ${ }^{12}$ The mission is then again surprised into three things: 1) unifying human religious and scientific differences universally, whether the difference is either in belief, nationality, caste or color of writing; 2) providing encouragement to undertake comparative studies between philosophy, religion, and knowledge; 3) revealing the hidden and unexplained potential of humanity. ${ }^{13}$

Developed in New York, the Teosofi Tariqa spread in almost all Western and Eastern states, but the fingers can almost count it by the time. Likewise, in Indonesia, the old Teosofi Tariqa reduced its quantity, not because its teachings and principles were irrelevant, but the attention of contemporary society shifted to the realms of pragmatism and conservatism. This makes any religious movement got less serious attention from society. ${ }^{14}$

In the 1920s, the Teosofi Tariqa developed rapidly in India. This could not be separated from the role of Anni Besant, who once held the chair of the association. The Teosofi Tariqa, which was at that time as a Besant the head of the Home Rule League organization

12 A.O. Herman De Tollenaere, The Politics of Divine Wisdom: Theosophy and Labour, National and Woman's Movements in Indonesia and South Asia 1875-1947 (Leiden: Katolieke Universiteit Nijmegen, 1996), 136.

13 The Theosophical Society was generally built in New York (USA) in 1975 by a group of occultists spearheaded by Helena Petrovna Blavatsky (1831-1891), a Russian woman, and Henry Steel Olcott (1832-1907), a veteran lawyer from the US. Ibid.

14 When viewed in detail, religious movements are growing quickly, starting from developing in a social direction. It was called socio-religious movements towards politics, which are called religious-political movements and others. For instance, LDII, originally a small group with theological studies, has now developed into a socio-religious organization located throughout the archipelago. According to Dodi's research (2017), LDII has turned into a heterodox group and an orthodox religious organization. This proved that religious movements or organizations fulfill important elements other than religion. Can be read in Limas Dodi, "Metamorfosis Gerakan Sosial Keagamaan: Antara Polemik, Desiminasi, Ortodoksi dan Penerimaan terhadap Ideologi Lembaga Dakwah Islam Indonesia (LDII)", al-Tahrir: Jurnal Pemikiran Islam, Vol. 17, No. 1 (2017), 244-245. 
and the president of the Indian National Congress Organization. ${ }^{15}$ Thus, the Teosofi Tariqa is now being booming and has developed in India. Then, Mahatma Gandhi came with a torch of the Teosofi Tariqa, and it blew up. In fact, the ancient old Indian wisdom cults the Teosofi Tariqa influenced the parts of the world, including Indonesia.

In Indonesia, especially in Java as the archipelago's cultural center, the Teosofi Tariqa was established in 1901 when the Indonesian state was still called the Dutch East Indies. Henry Steel Olcott, on September 7, 1901, inaugurated the Loge in Semarang, Central Java, as the base for the Teosofi Tariqa. On his journey, according to historians, in 1988, there was a loge (Loji) in Pekalongan led by Baron Van Tengnagel. In 1947, the Teosofi Tariqa in Java was recognized as the most influential tariqa. ${ }^{16}$ In fact, this tariqa is not only combing theological areas itself but also functions as a philanthropic forum to support education and welfare. The Theosophy groups resolved the conflict between the colonialists and the indigenous people through ethical associations and politics, which ultimately minimized conflict and drove the colonials.

In Java, including Surabaya, the Teosofi Tariqa was first chaired by Labberton. His role was able to become a central figure among the student elite in Java, especially among the priyayi of Boedi Oetomo. Even during a large gathering attended by 300 people in Java on January 19, 1909, Labberton said that he was photographing the vision of national awakening in Java. ${ }^{17}$ Since then, the Teosofi Tariqa in Java has developed to remote areas, changing from generation to generation.

\section{The Background of the Emergence}

The Teosofi Tariqa in Surabaya originally had its roots in India. This is justified because the archipelago culture is closely tied to religious rituals adopted from India, such as burning incense on Friday nights and giving offerings to objects that are considered

15 Pradipto Niwandhono, "Gerakan Teosofi dan Pengaruhnya terhadap Kaum Priyayi Nasionalis Jawa 1912-1926”, Jurnal Lembaran Sejarah, Vol. 11, No. 1 (2014), 26.

16 Van Hans Miert, Dengan Semangat Berkobar: Nasionalisme dan Gerakan Pemuda di Indonesia 1918-1930 (Jakarta: Hasta Mitra, 2003), 82.

17 Akira Nagazumi, Bangkitnya Nasionalisme Indonesia: Budi Utomo 1908-1918 (Jakarta: Pustaka Harapan, 2017), 122. 
guarded or believed to have mystical energy. All currents that come from India are easily absorbed and preserved by the archipelago. Therefore, Teosofi Tariqa developed rapidly in Java. As the Teosofi Tariqa mission, it is bridging people to lead to a peaceful, servant, and prosperous life.

Thus, the emergence of Teosofi Tariqa in Java—apart from its inculturation and assimilation from India-also had the main objective of breaking the chain of theological and social conflicts. In the 19th century, the current theological and social conflict was at an alarming pulse. Various religious denominations were born with ideologies splintered variously, this made the position of the average society an ordinary dilemma, creating social tension and confusion. Therefore, the nativity of the Teosofi Tariqa in Java, namely, first the concern over the various conflicts of ideological contradictions of religious movements that were rife. The conflict between Kejawen Aboge (traditional Javanese teaching) and indigenous religions is one of this conflict's portraits. The nativity of the Teosofi Tariqa tried to reconcile religious conflicts.

Second, concerning the scientific way of thinking that confuses the Javanese people's perspective. In this case, the Teosofi Tariqa work is concerned about scientific irregularities that can open the gates of religious error. Such as the confusion of thinking about Darwin's materialistic theory of evolution. This theory makes scientific science, lame because logically, people have ordinary conflicts. Thus, science paused and underdeveloped.

Third, intellectual and religious unity made the Teosofi Tariqa became a movement quasi-religious when it was a forum that embraced all community conflicts, whether related to religion, science, or the state. Because according to their understanding, all elements on earth, such as individual, social, natural, scientific, cultural, are a coherence unity. The Teosofi Tariqa, in its development, was determined to solve problems related to this. ${ }^{18}$

From this background came the basic principles of the Teosofi Tariqa as outlined by Blavatsky (1887) in his book ISIS Unveiled and the Secret Doctrine. The basic principles of the Teosofi Tariqa are first, the absolute existence of God is one with all the components of human life, nature, and all creature. So every human movement thought, and

18 Savitri Prastiti Scherer, Keselarasan Kejanggalan: Pemikiran Priyayi Nasionalis Jawa Awal Abad XX (Jakarta: Pustaka Sinar Harapan, 2009), 17. 
the creator controls activity. Second, the existence of the cosmos (nature) is imprinted on a cycle called causality; that is, the function of nature has a reciprocal relationship with other creatures. Third, all living cells are attached to the universal soul. This means that every human being has rights and obligations to make the social environment and other harmonious aspects. ${ }^{19}$

In Java, one of the founders of the Teosofi Tariqa was RM Soeta Mo Soeryo Koesoemo (1888-1924), a religious expert who was recognized by the Javanese community. Besides being a priyayi (represents the high gentry class of social community), he is also genealogically descendants of the Paku Alaman dynasty, and there are still family ties with Ki Hadjar Dewantara. Soetatmo himself was known to be a nobleman who studied spiritual rituals with Soewardi Soerjaningrat as part of a member of a Javanese mystical group called the Kliwon Tuesday Group. Soetatmo's thinking is known for its integrative style between Javanese mystical and nationalism. He rejected the liberal western of religious movements, Islamism and Marxism. $^{20}$

He disagrees with modernist thinking by removing traditionalism as a whole and anti-feudal. According to him, the idea of a spiritualist is internalized in real life, be it the state, politics, economy, and so on. Most of the theosophers see society as a liberal democratic figure and unable to maintain local wisdom from policymakers.

Exactly in 1917, the Comite Voor het Javaans Nationalisme founded by Soetatmo was founded, a purely theosophical movement. The main vision that motivated this committee's establishment was to restore Javanese culture to an honorable position in Southeast Asia. Javanese culture that has developed a lot outside the archipelago, and creates friction of interests and annexation of regional cultures.

Until now, Untung Susilo, the Teosofi Tariqa leader, has continued his previous leadership. When it is viewed, the continuity of leadership is continuous. Leaders are chosen based on the length of time they joined and are considered to be the most understanding

19 Joy Dixon, Divine Feminine: Theosophy and Feminism in England (Londong: The John University, 2001), 66.

20 The shifting of religious movements can be seen in Alamul Huda, "Epistemologi Gerakan Liberalis, Fundamentalis dan Moderat Islam di Era Modern”, De Jure: Jurnal Syariah dan Hukum, Vol. 2, No. 2 (2010), 179. Also see Marx and Engels on Limas Dodi, "Ideologi Agama", 196. 
and practicing leaders. Fortunately, Susilo joined the Teosofi Tariqa from 1985 up to now. ${ }^{21}$

\section{The Result and Analysis of the Research}

The location of the building of Teosofi Tariqa is in Surabaya, right in the city center, but many people do not realize it because they are not the members. Researchers witnessed themselves by observing directly when the meditation or ritual of the Teosofi Tariqa took place in the city of Surabaya. At that time, about 30 congregations appeared to be doing dhikr (forgiveness chanting), joking, or studying books written by their predecessors. When one figure entered, all the congregation stopped and focused on what that figure would do. Untung Sosilo, once the congregation knew him as the head of the Teosofi Tariqa in the city of Surabaya up to now.

The researcher saw with the five senses directly, as well as data participant observant (where the researcher appeared as a congregation). The congregation's head came to the seat in front, looking one by one at the congregation present. There is a simple green table made of teak wood in front of him, and there is a red cap, a bottle of sand, and a small bell on the table. You can see a wooden board with a circular snake painted on it above the congregation's head. After you look at the wooden board, Daud's star and a symbol of ancient Egyptian humans are drawn. At that time, the congregation leader took the bell and swung it once and closed his eyes while praying; this ritual was a sign that meditation began.

Totally, the number of members who attended was around 30 people. However, according to information, not all members of the Teosofi Tariqa in Surabaya were present during meditation or rituals. Some choose to practice at home and preach to the homes of people who want to know the Teosofi Tariqa in the city of Surabaya. The head of the Teosofi Tariqa did not require that rituals be carried out at places of worship. It could be anywhere and anytime. Quoted from Untung Susilo, that:

"Religion is not binding; religion gives freedom to its adherents.

Even though there are rules, these rules do not bind goodness

but prevent people from doing anything bad. So what is the point of obliging the congregation to do ritual together, the main

${ }^{21}$ Reno Surya, Menemui Jemaat Teosofi Terakbi Surabaya, Yang Kerap Dianggap Kelompok Freemason dalam https://www.vice.com/id_id/article/v7geg3/kiprah-kelompokteosofi-di-indonesia-masih-ada-di-surabaya-terkait-freemason 
thing in our ritual is to practice it. Some congregants participate in the ritual twice a week; some are at their homes; some are visiting the houses. Our teaching is not burdensome to the followers, because our real goal is yes (the harmony of theology and the stability of man and nature)."22

Almost all the Teosofi Tariqa congregations in the city of Surabaya are educated people. Some even write and write books. According to one statement, the Teosofi Tariqa congregation in Surabaya had the lowest education with a degree and consisted of scholars. No doubt, those who joined have gone through reading, discussing, and deepening their hearts about the Teosofi Tariqa. The teaching of the Teosofi Tariqa is considered the most complete of the tariqa compared to other tariqas. Rudiyanto explained:

"Everything that is contained exists is formed in the heavens, and the earth is discussed in the Teosofi Tariqa. Such as animals, the solar system, planets, humans, nature, planets, even the superhumans, all of them are targets and objects studied by the teachings of Teosofi. We know for ourselves, "the" means divine or divine, while "soft" means knowledge. If combined the meaning of teosofi is the knowledge of divinity. The word "God" itself is a very large and absolute substance." 23

The term Teosofi (theosophy, in English) uses other terms such as sekte, sect, splinter, and religious movements as contemporary terms. Teosofi is a religious stream as a philosophical doctrine of religion and mysticism. ${ }^{24}$ In general, theosophical teachings hold that all religions (Islam, Christianity, Confucianism, Buddhism, Hinduism, and so on) are an effort of the occult community to achieve perfection, so the goal of all religions is goodness and truth. ${ }^{25}$ So, how ideological flows as a splitter also has right and good qualities.

\footnotetext{
22 Untung Susilo, Interview, Surabaya, November 12, 2019.

23 Rudiyanto, Interview, Surabaya, November 12, 2019. Rudi is a young, knowledgeable figure with a master's degree in Teosofi Tariqa. Besides, Rudi is known as a figure who diligently reads and writes books, especially on Teosofi. Rudi often became as a speaker that used to be as a reference and knowledge. Rudi has read more than 5,000 books on theosophy. So that he concluded that all the tariqa he met were only the most comprehensive of Teosofi Tariqa.

${ }^{24}$ Niwandhono, "Gerakan Teosofi", 25.

25 Embracing all groups or understanding that all different religious teachings are the same is the embryo of the way liberals cover religious pluralism conflicts. This tariqa has in common with liberal perceptions in its basic and foundation contexts as a source of understanding. See the source of liberal understanding in Mohd Fairuz Jamaluddin; Latifah Abdul Majid, "The Perception on Liberal Islam Thought
} 
Teosofi Tariqa is a religious ritual existing for a long time in Surabaya, East Java. This group is the only theosophical school that can survive in Indonesia with many congregations. The Dutch colonialists recognized its existence as a purely religious movement that upheld human values. The ideology used is tolerant, harmonious, harmonious, and non-doctrinal. His followers were Muslim, from Konghuchu and Catholicism, converting to Islam to become part of the Teosofi Tariqa.

If there are many religious movements or schools in Indonesia whose concepts and ideals have a religious-theological central character, the Teosofi Tariqa is even more comprehensive. Apart from theological aspects, philosophical and scientific studies are the main principles. In between interviews, Rudiyanto stated that the Teosofi Tariqa was teaching that did not indoctrinate followers or society but instead encouraged the congregation to think, study, and learn about the logical values contained in the Teosofi Tariqa. ${ }^{26}$

By carrying out the dialectic of science, social, and theology, the Teosofi Tariqa in the city of Surabaya belongs to a religious sect which, on one side, has religious characteristics, on the other hand, also has a social and knowledge background. It reminds the author of the assumption made by Azyumardi Azra that religious character is influenced by social realities and scientific developments so that followers do not abandon the movement, it must be improved. ${ }^{27}$

To obtain a comprehensive ideology, Teosofi Tariqa in Surabaya carried out three main principles, namely study, meditation, and dedication, or in short, we call SMP. It is not only true in the aspects of religion, philosophy, and mysticism. The following things described the research results in more detail regarding the rituals, principles, and thought constructs of the Surabaya Teosofi Tariqa. Research on the three main principles is portrayed from sources of rational thought and ritual.

Among Islamic Studies Students in IPTS", Jurnal Hadhari, Vol. 5, No. 1 (2013), 1 19.

${ }^{26}$ Rudiyanto, Interview, Surabaya November 15, 2019.

27 Kuntowijoyo reinforces this opinion that the dynamics of a sect's character has a relationship with pravastatin and social change. See Kuntowijoyo, Paradigma Islam: Interpretasi untuk. Aksi (Bandung: Mizan, 1998), 204; also can be seen in Azyumardi Azra, Konteks Berteologi di Indonesia: Paradigma Islam (Jakarta: Paramadina, 1999), 10. 


\section{Source of Thought of Teosofi Tariqa}

The Teosofi Tariqa in Surabaya is located in the city center, simple and such an ordinary building. The ritual building of the Teosofi Tariqa has a colonial style that has been a camp or headquarters since 1908, the entrance to the building location is not so many, only a sign of a rotten wooden board that says "lighting studio" and in front of the building written as the Teosofi Tariqa. Besides the building, there is a church and a mosque in the east. However, all people are tolerant. It mentioned that tolerance and religious diversity were caused by the existence of the ancient Teosofi Tariqa.

The principles of the ritual teachings of the Teosofi Tariqa in Surabaya is departed from philosophical and mythological studies as sources of birth epistemology and studies twice a week. Philosophy is the core value behind the principles of the Teosofi Tariqa. A philosophical foundation built it; philosophy is interpreted as reasoning to understand God, man, and nature as the basis of thought and movement. Meanwhile, the mystical meaning is a ritual that has been practiced as a form of devotion and totality of servitude to the almighty power. Below are the main sections of philosophy and mysticism.

First, God, humans, and nature are hierarchical structures that have a close relationship. God is described as an absolute power, which becomes absolute to regulate and guard human life and nature. This illustrates how the Teosofi Tariqa of the City of Surabaya embraces the principle of absolute theology as expressed by Zalachu that absolute theology is a teaching absolute and elastic divinity. ${ }^{28}$

Borrowing the language of one of the congregations, namely Untung Susilo, he said:

"Religion is the same, both gods. While God is right, then why do creatures or humans blame each other? What is wrong is not the religion, but the way of religion, that needs to be changed. We often encounter many religious followers who are unable to hold back their emotions, seeing different ways. Even though worship may be different, the goal is the same, namely both towards the almighty God. The existence of the Teosofi Tariqa intends to bridge these differences to become the same. ${ }^{29}$

\footnotetext{
${ }^{28}$ Sonny Eli Zaluchu, "Mengkritisi Teologi Sekuralisasi”, Jurnal Kurios: Teologi dan Pendidikan Agama Kristen, Vol. 4, No. 1 (2018), 26-38.

${ }^{29}$ Untung Susilo, Interview, Surabaya, November 16, 2019.
} 
If you pay attention, the Teosofi Tariqa promotes tolerance along with religious diversity. This is different from most theology or religious movements, which in one direction focus on theology without tolerance for religious diversity, in the other direction on promoting religious tolerance without a centralized theology as stated by Michel Hill (1996) that the alienation of theological schools, because they are too focused on their concept of ritual without looking at other theological rituals. In other words, it could be ignoring other different religious problems. ${ }^{30}$

Humans and nature are forms of love which has cause and effect. Humans must not destroy nature, because the impact results in nature not supporting human happiness and psychology. Natural disasters that occur, such as floods, tsunamis, volcanic eruptions, and the like-according to their understanding - are the cause and effect of human attitudes; if humans respect nature, then nature also respects humans, and vice versa. The relationship between humans and nature is a part of the pattern of the construct of religiouscultural thoughts, as stated by Martin van Bruinessen that the pretext of human integration with nature gives birth to the construct of religious thought and meaning. ${ }^{31}$

One of the wise words mentioned, "oh ... hidden life, vibrating at every atom", is the framing's form. Hidden life means that God is a supreme being, cannot be seen by the eye but felt on every breath, ritual, and wherever they are. Thus, in what the activity goes, they think there is a God who sees. "Which vibrates in every atom" means that God is in all the joints of life, seeing with certainty. Thus, humans and nature are obliged to understand and have a shame when they do damage. This feeling is similar to the meaning of "special" in Islamic teachings, where Allah "watches" in every human behavior. ${ }^{32}$

The second, scientific rationality. This is one of the differences with other tariqa movements. The Teosofi Tariqa studied every ritual and principle with science, not just belief and belief. Like the universe, this group never believes in ritual worship of trees, graves, spirits, or

\footnotetext{
${ }^{30}$ Michael Hill, "Sect in Mircea Eliade", in Encyclopedia of Religion (New York: Simon Macmillan, 1996), 155.

31 Martin van Bruinessen, Rakyat Kecil, Islam, dan Politik, trans. Farid Wajidi (Yogyakarta: Yayasan Benteng Budaya, 1999), 245.

32 M. Hafiun and Nurjannah, "Pengembangan Modul Bimbingan Shalat Khusus Berbasis Paradigma Integrasi Interkoneksi Guna Membentuk Karakter Positif dan Kebermaknaan Hidup Muslim”, Jurnal Misbah, Vol. 12, No. 2 (2015), 60-76.
} 
anything else. Even though they believe in the mystical, they understand differently from mystical in general. The mystical that they understand is the methodology, namely rituals non-logical, that still have a scientific explanation. Religious rationalization is similar to revivalism's teachings; they divide the truth into two things; rationalizable truths and truths that only God knows. ${ }^{33}$ As the opinion of Rudiyanto:

"I was interested because his teaching made sense, not only talking about divinity or theology, but non-logical things followed. This is the same as taking part, not from conscience or the results of studies. The Teosofi teachings offer rationalization in various things, including humans, nature, and so on. For example, the deed determines the guarantee of heaven and hell. Those who do good will go to heaven, and vice versa, those who do bad will go to hell. This makes sense. If you plant rice, what you will harvest is rice. However, if thorns are planted, it can harm others." 34

"Ob hidden light, shining in every creature" is the watchword to illustrate this principle. "Hidden light" means that nature, through the moon and stars, has a light that illuminates human life. However, this is not the desire of the moon and stars as creatures, but by God's command. Thus, God is understood as the ruler of light above the light. Light, either, is a scientific principle that originates from atoms and geometry. The meaning of light can be scientifically responsible.

From this fact, the construction built in the Teosofi Tariqa in Surabaya was intellectual and agency. K. Nottingham (1997) stated that a religious movement that is influenced by way of thinking based on science or intelligent agents is a cooperative religious character. It was called cooperative, because it is relevant to any situation and in other positions sometimes makes thoughts filterer). ${ }^{35}$

Third, natural methodology, that is, every ritual (prayer) that is practiced, is a building for submitting, acknowledging, and worshipping God. The creation of the universe, humans, and jinn essentially aims to maintain harmony with each other. Nature was created so that humans could live and be independent; humans were created to carry out God's commands and prohibitions, while the jinn was created to

\footnotetext{
33 Huda, "Epistemologi Gerakan Liberalis", 181.

${ }^{34}$ Rudiyanto, Interview, Surabaya, November 17, 2019.

35 See Elisabeth K. Nottingham, Agama dan Masyarakat, trans. Abdul Muis Nahaarong (Jakarta: Raja Grafindo, 1997), 155.
} 
serve God. All creatures walk with their respective duties, not disturbing, destroying, or hostile. Here, Untung Susilo emphasized that:

"Many people consider our prayers as a mythical thing, or absurd. Actually, values are not attached to things that are visible in nature. The most important thing is to pray for all God's creatures on earth. All beings pray for each other according to their respective abilities and their lives. Even though it is considered a myth, it continues to become a mythology of worship if it is taught. God certainly does not judge sound or speech, but heart and writing are the main sources." 36

Ob bidden love, which embraces all of them in unity, is the watchword that illustrates this principle. "Love" is defined as a harmonious relationship between all beings under the divine corridor. At first glance, this is mystical, but philosophically, humans need God, nature needs humans to be maintained, so humans need nature. This is the principle of harmony through the unity of every particle and creature. Thus, the construct of the Teosofi Tariqa of Surabaya combines thinking with divinity, which in the process begins with the assumption of divinity, society in nature. ${ }^{37}$

The researcher asks for documentation of what was practiced to start the ritual in a very special way, the following reads:

Ob bidden life

That vibrates in every atom

Ob bidden light

That shines in every creature.

Ob bidden love

\section{That embraces all of them in unity}

May those who feel one with You

Know that they are one with each other. ${ }^{38}$

From several sources, this practice is a core part of all the teachings of the Teosofi Tariqa. Every week, the leadership explains

\footnotetext{
36 Untung Susilo, Interview, Surabaya, November 18, 2019.

37 The combination of theological concepts and humanism is described in the teachings of radical revivalism, which builds the two concepts as a hierarchical building, not parallel like theological teachings. Ilim Abdul Halim, "Gerakan Sosial Keagamaan Nahdhatul Ulama Pada Masa Kebangkitan Nasional”, Religious: Jurnal Studi Agama-Agama dan Lintas Budaya, Vol. 2, No. 1 (2017), 50.

38 Adapted from the book Teosofi Tariqa called "Teosofi" and validated through interviews with Untung Susilo, Interview, Surabaya, November 23, 2019.
} 
the meaning of the sentences that are practiced. In essence, according to one member, if you especially read this sentence, you will feel a calm heart, as if God, who is powerful, is felt to the pulse. But to feel this requires practice (riyäalah), which istiqamah and consistent in order to reach The Divine.

\section{Rituals of the Theosophy}

Congregations of the Theosophy in the City of Surabaya gather every week or two every odd week. Meanwhile, at other times, it is used to broadcast the teachings of the Teosofi Tariqa to congregation houses and communities both inside and outside the city of Surabaya. Each generation is able to recruit 20 members, but over time, due to age, many congregations are more often at home and have died. Because of its open teachings, Teosofi Tariqa of Surabaya belongs to a type of religious movement that is rational-inclusive. The epistemology is logical and rational, and the spread of its teachings is open and transparent. ${ }^{39}$

The meditation ritual that is carried out, as observed, is when the congregation gathers in a building filled with studies and conversations about philosophy. After the Teosofi Tariqa leader sounded the bell, the congregation began to close their eyes while making a circle. After that, they started meditation with the prayers they had memorized. Prayers are read live fully, without stopping and continuing to close their eyes in a low but trembling voice. The entire congregation seemed to have understood the contents of the prayer. As the original quote from the respondent on behalf of Untung Susilo:

"We do the ritual twice a week regularly, but that does not mean it is mandatory for the congregation. Its purpose is contemplation and meditation. We started by ringing the bell to signal the ritual's start and then closed our eyes by reciting the prayer we were saying. After that, I filled out a study on the meanings of divinity, man, and nature. Then, the congregation enters the spiritual realm to experience the power of God."

In general, this prayer is a manifestation of the Theosophical Order's principles, namely the servitude of the totality to God,

\footnotetext{
39 Rational-inclusive emphasizes tolerance and embraces all groups. A form of religious thought that uses reason openly either through scientific studies or barakah ijtimāíryya rituals. Halim, "Gerakan Sosial Keagamaan”, 45.

40 Untung Susilo, Interview, Surabaya, November 18, 2019.
} 
harmony between beings, and religious morality. Apart from theology, humanity, as an element of culture, is in the spotlight, developing theological-cultural constructs. ${ }^{41}$ After the meditation was held for almost two hours, the Teosofi Tariqa head opened a study room by inviting people to raise godly awareness, harmonize and prosper the various religious communities, and maintain their harmony. The following describes the concept of rationality, namely:

First, worldly rationalization. The basis of the Teosofi Tariqa is not in the realm of religion or theology itself, like most other religious schools, but Teosofi Tariqa offers rationalization in various ways. The most important things are that the Teosofi Tariqa teaches the equality of all religions. All religions share a vision of leading humankind to goodness in the world and hereafter. Such a matter of law "sow reap" as a concept of life, which means causality. This is followed and believed by all religions, such as Islam and Christianity. Untung Susilo added:

In Islam, it is also taught, if it is not a religion, its name if it cannot be guessed by reason. Except for things that cannot be rationalized, such as where God is, miracle, heaven-hell, and so on. However, the metaphysical thing is right in its place. Now it sunnatullab's turning to show his rational side so that it can be accepted by reason". 42

For example the Bible, in James, there is a verse which says that "the fruit which is ripe/ripe will be ripe when it is going to be dead because it will come down and people will receive the consequences. Meanwhile, in the Qur'an it is also explained that "human actions will be returned to him as if their own deeds punished them". Thus, from the contents of the two books, it says that "what they did; good or bad, it will come back to him".

With this understanding, the concept of causality can be rationalized. However, according to Dickinson and Shanks, the concept of religious causality is open and comprehensive- a model of causality like this is easy to apply because it embraces all sciences. ${ }^{43}$

\footnotetext{
41 An emancipatory-transformative religious approach, namely, making the human side the object or target of understanding theology. Nunu Buhanuddin, "Gerakan Sempalan Ahmadiyah: Dari Fenomena Urban Keagamaan Reformis ke MessianisIntroersionis", Islam Realitas: Journal of Islamic dan Social Studies, Vol. 1, No. 2 (2015), 150.

42 Untung Susilo, Interview, Surabaya, November 18, 2019.

43 Dickinson's theory of causality is called the counterfactual theory, where the cause of what happens is a conditional effect, see in A. Gopnik, Causal Learning:
} 
The theological element is used as the basis for humanizing humans (transformative emancipation). ${ }^{44}$ Aloud to say, the Teosofi Tariqa warded off other theological thoughts or religious movements that often made religion (theology) as an excuse to cover up interests. However, in the Teosofi Tariqa, this was not the case; instead, the existence of theology or divinity was used as the basis for humanizing human efforts. In the pilot, the researcher borrowed the Untung Susiolo language, as follows:

"For example, all religious sects certainly do not always agree that it is permissible to commit stealing, brutality, or harm to others. Of course, the reason is that not only the aspect of religion is brought up, but from the human side, it is also wrong. Even though it has not been informed by religious science, human conscience must have realized and understood. Then why is the conflict between religions considered right? This is weird. There are religious teachings that are hostile, fighting, and blaming each other, logically, it is incorrect. Our rituals are rational. Prayers are said because as a creature, they must obey God. It is closing your eyes as a sign of submission and specialization. The gathering is the order of all religions." 45

Second, non-doctrinal. The main characteristic of a religious movement is a doctrine, namely, gathering as many congregations as possible to become popular and recognized. However, for the Teosofi Tariqa, this was considered odd because it sacrificed individual freedom to choose and believe without coercion. The Teosofi Tariqa considers the division of religions in Indonesia or its streams to be caused by "coercion" and "doctrinal" that are often mobilized. Thus, each other thinks that what they believe is true. Whereas according to the Teosofi Tariqa, ideology is not just a "belief" but can purify the human mind and soul. Thus, the Teosofi Tariqa of the City of Surabaya actually also has the power of da'wa (an Islamic way to convey the Islamic teaching), but the preaching

Psychology, Philosophy, and Compulatation (New York: Oxford University Press, 2007), 26.

${ }^{44}$ Buhanuddin, "Gerakan Sempalan Ahmadiyah", 147

45 Untung Susilo, Interview, Surabaya, November 18, 2019. 
carried out is "eclectic", where people are not forced but attracted to it. $^{46}$

The devotion, meditation, and teachings of the Teosofi Tariqa have no doctrine. Even its adherents feel they are following on impulse. There is no doctrinal element in it; there are studies of science and philosophy that can display a feeling of surrender to God with the process of the tariqa being undertaken. Indirectly, the Teosofi Tariqa principle is science and, at the same time, creating moral human beings to serve God. As Untung Susilo said, in an interview on November 18, 2019:

"Adhering to religion is not forced, indoctrinated, or seduced by anything. Religion is not coercive. Even in our teachings (Teosofi Tariqa) our children, wives, relatives, parents, and all those who are related by blood or not, we do not insist. Please choose your path. Our task is only to provide a logical and reasonable understanding because there are so many religions and theologies in the world, but this number is also directly proportional to the conflicts that occur, one of which is due to compulsion/doctrinality. ${ }^{47}$ The Teosofi Tariqa is like a heart calling. The first time I entered, I listened to this teaching. There happened to be a studio next to my school in Blitar, Central Java. I immediately followed this teaching because it was very rational and haqq al-yaqin without doctrine. ${ }^{48}$

If it was analyzed, the Teosofi Tariqa has a rational and open type (not doctrinal). The type of religious movement that displays an open, open understanding of religious teachings and has the principle of rahmat li al-älamin (The Blessing of the God). This Teosofi Tariqa is tolerant and advocates that all humans can understand religion; religion is a way of life for all humans. Thus, it causes tolerance, pluralism, liberalism, elasticity, and moderation. The community is only given knowledge; there is no indication that they must participate.

In another ritual, the Theosophical Congregation's activities in Surabaya took two forms; in places of worship and homes and the community. Between the three of them have a hierarchical

\footnotetext{
${ }^{46}$ C. Moreira Escudero and C. Caballero, "A Research on Undergraduate Students Conceptualizations of Physics Nation's related to non-sinding Rotational Motion", Phys Educ Journal, Vol. 3, No. 1 (2009), 1-7.

${ }^{47}$ Untung Susilo, Interview, Surabaya, November 18, 2019.

48 Rudiyanto, Interview, Surabaya, November 22, 2019.
} 
relationship, at first, it begins with praying at a special place of worship and is led by the Teosofi Tariqa head, namely Untung. From this prayer, peace of heart can be obtained and creates social awareness, humanizes people, and loves fellow people. When all the congregation has finished praying, the leadership of the Teosofi Tariqa closes the prayer as follows:

Divine rays create me

Divine rays refute me

Divine rays protect me

Divine rays surround me

I develop from divine rays

Ob ... the sun. ${ }^{49}$

According to Untung and several members, this prayer illustrates the confidence that God answers their prayers. The term "light" is God's power and compassion for all creatures, whether humans, animals, or plants. Starting from the "process of creation in the womb", when growing up being guarded and guarded by God (refuted and protected), then at the age of 40, God developed and matured the thoughts and patterns of human feelings, like the Prophet Muhammad, who was appointed as an apostle at the age of 40 of year.

Having the closing prayer illustrates that the Teosofi Tariqa fully understands the process of human development, indicating that the study of philosophy has truly become the principle of its teachings. This study model is transformative in religious typology. In the study of philosophy, it is known as constructive humanism, which is taking lessons from God's human process to increase confidence and trust. ${ }^{50}$

\section{Concluding Remarks}

From the explanation of the research results above, it can be concluded that the Teosofi Tariqa in the City of Surabaya has the principles of tolerance and diversity like all religions and religious movements, both Islam and other religions. The conflict of religious ideology that occurs is caused by the attitude of egoism and the assumption of "belief" that is forced, even though the essence of

\footnotetext{
49 Adapted from the book Theosophical Order called "Teosofi" and validated through interviews with Untung Susilo, Interview, Surabaya, November 23, 2019.

50 Buhanuddin, "Gerakan Sempalan Ahmadiyah", 148.
} 
religious teachings is to purify the soul, mind, and spirit. The teachings of the Teosofi Tariqa teach about mysticism and meditation as a form of worship to the absolute God with rational studies and understanding.

The Teosofi Tariqa unites theological and meditative elements in the realm of rational, scientific, and scientific relevance. This is because science is the essence of reason in human life. Thus, the Teosofi Tariqa puts three teaching concepts into the priority, namely study (as a form of philosophy and science), meditation (as a form of servitude and expression of human identity), and devotion (as a form of harmonization and integration between humans and nature).

\section{References}

\section{A. Book and Journal}

"Minoritas Paling Berbahaya: Islam Radikal di Indonesia", in https://www.matamatapolitik.com accessed on Agustus 11, 2019.

Azra, Azyumardi. Konteks Berteologi di Indonesia: Paradigma Islam. Jakarta: Paramadina, 1999.

Brenen, Julia. Memadu Metode Penelitian: Kualitatif dan Kuantitatif. Yogyakarta: Pustaka Pelajar, 2005.

Bruinessen, Martin van. Rakyat Kecil, Islam, dan Politik, trans. Farid Wajidi. Yogyakarta: Yayasan Benteng Budaya, 1999.

Buhanuddin, Nunu. "Gerakan Sempalan Ahmadiyah: Dari Fenomena Urban Keagamaan Reformis ke Messianis-Introersionis", Islam Realitas: Journal of Islamic dan Social Studies, Vol. 1, No. 2, 2015.

Burhan Bungin, Penelitian Kualitatif: Komunikasi, Ekonomi, Kebijakan Publik, dan Ilmu Sosial Lainnya. Jakarta: Kencana Prenada Media Group, t.th.

Escudero, C. Moreira and Caballero, C. "A Research on Undergraduate Students Conceptualisations of Physics Nation's related to non-sinding Rotational Motion", Phys Educ Journal, Vol. 3, No. 1, 2009.

Dixon, Joy. Divine Feminine: Theosophy and Feminism in England. Londong: The John University, 2001.

Dodi, Limas. "Antara Spiritualitas dan Realitas Tarekat Shiddiqiyyah dalam Bingkai Fenomenologi Annemarie Schimmel", Prosiding Nasional Pascasarjana IAIN Kediri, Vol. 1, No. 1, 2018. 
-----. "Ideologi Agama dalam Praktik Dominasi antara LDII Versus Non-LDII di Jombang", Teosofi: Jurnal Tasanuf dan Pemikiran Islam, Vol. 8, No. 1, 2018.

-----. "Metamorfosis Gerakan Sosial Keagamaan: Antara Polemik, Desiminasi, Ortodoksi dan Penerimaan terhadap Ideologi Lembaga Dakwah Islam Indonesia (LDII)", al-Tabrir: Jurnal Pemikiran Islam, Vol. 17, No. 1, 2017.

Gopnik, A. Causal Learning: Psychology, Philosophy, and Compulatation. New York: Oxford University Press, 2007.

Hafez, Mohammed. "Dari Peminggiran ke Pembantaian" in Quintan Wictorowicz, Aktivisme Islam: Pendekatan Teori Gerakan Sosial. Jakarta: Balitbang Kemenag, 2007.

Hafiun, M. and Nurjannah. "Pengembangan Modul Bimbingan Shalat Khusus Berbasis Paradigma Integrasi Interkoneksi Guna Membentuk Karakter Positif dan Kebermaknaan Hidup Muslim", Jurnal Misbah, Vol. 12, No. 2, 2015.

Halim, Ilim Abdul. "Gerakan Sosial Keagamaan Nahdhatul Ulama Pada Masa Kebangkitan Nasional”, Religious: Jurnal Studi AgamaAgama dan Lintas Budaya, Vol. 2, No. 1, 2017.

Hill, Michael. "Sect in Mircea Eliade", in Encyclopedia of Religion. New York: Simon Macmillan, 1996.

Huda, Alamul. "Epistemologi Gerakan Liberalis, Fundamentalis dan Moderat Islam di Era Modern", De Jure: Jurnal Syariah dan Hukum, Vol. 2, No. 2, 2010.

Ismail, Faisal. "The Nahdlatul Ulama: Its Early History and Contribution to the Establishment of Indonesian State", Journal of Indonesian Islam, Vol. 5, No. 2, 2011.

Jamaluddin, Mohd Fairuz and Majid, Latifah Abdul. "The Perception on Liberal Islam Thought Among Islamic Studies Students in IPTS”, Jurnal Hadhari, Vol. 5, No. 1, 2013.

Kuntowijoyo. Paradigma Islam: Interpretasi untuk Aksi.Bandung: Mizan, 1998.

Miert, Van Hans. Dengan Semangat Berkobar: Nasionalisme dan Gerakan Pemuda di Indonesia 1918-1930. Jakarta: Hasta Mitra, 2003.

Mubarak, M. Zaki. "Dari NII ke ISIS: Transformasi Ideologi dan Gerakan dalam Islam Radikal di Indonesia Kontemporer", Jurnal Episteme, Vol. 10, No. 1, 2015.

Nagazumi, Akira. Bangkitnya Nasionalisme Indonesia: Budi Utomo 19081918. Jakarta: Pustaka Harapan, 2017. 
Niam, Khoirun. "Nahdhatul Ulama and the Production of Muslim Intellectuals in the Beginning of $21^{\text {st }}$ Century Indonesia", Journal of Indonesian Islam, Vol. 11, No. 2, 2017.

Niwandhono, Pradipto. "Gerakan Teosofi dan Pengaruhnya terhadap Kaum Priyayi Nasionalis Jawa 1912-1926”, Jurnal Lembaran Sejarah, Vol. 11, No. 1, 2014.

Nottingham, Elisabeth K. Agama dan Masyarakat, trans. Abdul Muis Nahaarong. Jakarta: Raja Grafindo, 1997.

Scherer, Savitri Prastiti. Keselarasan Kejanggalan: Pemikiran Priyayi Nasionalis Jawa Awal Abad XX. Jakarta: Pustaka Sinar Harapan, 2009.

Siregar, Sawaluddin. "The Pattern of Religious Understanding of the West Pasaman Simpang Empat Community (Study of the Haqqul Yaqin Sect of the Naqsabandiyah Tarekat)", Fitrab: Jurnal Kajian Ilmu-Imu Keislaman, Vol. 4, No. 1, 2018.

Sugiyono. Metode Penelitian Kuantitatif Kualitatif dan R \& D. Bandung: Alfabeta, 2014.

Tedy, Armin. "The Mutabaroh Tarekat in Indonesia (Study of the Shiddiqiyyah Tarekat and Its Teachings)", Jurnal El-Afkar, Vol. 6, No. 1, 2017.

Tollenaere, A.O. Herman De. The Politics of Divine Wisdom: Theosophy and Labour, National and Woman's Movements in Indonesia and South Asia 1875-1947. Leiden: Katolieke Universiteit Nijmegen, 1996), 136.

Wahid, Ramli Abdul. "Aliran Minoritas dalam Islam di Indonesia", Journal of Contemporary Islam and Muslim Societies, Vol. 1, No. 2, 2017.

Zaluchu, Sonny Eli. "Mengkritisi Teologi Sekuralisasi", Jurnal Kurios: Teologi dan Pendidikan Agama Kristen, Vol. 4, No. 1, 2018.

\section{B. Interview}

Rudiyanto. Interview. Surabaya November 15, 2019.

----. Interview. Surabaya, November 12, 2019.

----. Interview. Surabaya, November 17, 2019.

----. Interview. Surabaya, November 22, 2019.

Susilo, Untung. Interview. Surabaya, November 12, 2019.

----. Interview. Surabaya, November 16, 2019.

----. Interview. Surabaya, November 18, 2019.

----. Interview. Surabaya, November 23, 2019. 